\title{
Operational Performance of Indian Scheduled Commercial
}

\section{Banks-An Analysis}

\author{
Dr. M. Syed Ibrahim \\ Assistant Professor of Commerce \\ Govt. Arts College (Autonomous) \\ Salem--636 007, Tamil Nadu, South India \\ E-mail: syedibrahim_66@yahoo.co.in
}

Received: November 30, 2010

Accepted: March 9, 2011

doi:10.5539/ijbm.v6n5p120

\begin{abstract}
The banking sector is the core segment of the Indian financial system which decides the progress of the country. Banks play an important role in the mobilization and allocation of resources in an economy. The sound financial position of a bank is the guarantee not only to its depositors but equally important for the whole economy of the nation. Several committees have emphasized the need to improve the performance of the commercial banks. In India, the priorities in banking operations underwent far reaching changes since the banking sector reforms have been set in motion. In this paper, an effort has been made to evaluate the operational performance of the commercial banks in India with especial reference to the Scheduled Commercial Banks since 2000. The study is diagnostic and exploratory in nature and makes use of secondary data. The study finds and concludes that the Scheduled Commercial Banks in India have significantly improved their operational performance.
\end{abstract}

Keywords: Deposits, Investments, Credits, Loans and advances, Reserve Bank of India

\section{Introduction}

Modern banking developed around 500 years ago in other countries and 200 years ago in India. The Indian financial system comprises a vast net work of different banks. The banking sector is the core segment in deciding the progress of the entire economy of the country. Activities of a modern economy are significantly influenced by the functions and services of banks and became an indispensable part of socio-economic life of the people. Banks not only accept the deposits from the public and deploy large amounts of uncolletateralised public funds in a fiduciary capacity, but also leverage such funds through the process of credit creation. In India, the banking sector was restricted mainly to the urban areas and neglected in the rural and semi-urban areas. After the nationalization of 14 major banks in 1969 and six more in 1980, the scenario changed. Since then the banking sector in India has played a pivotal role in the Indian economy. The Indian commercial system comprises two groups i.e., Scheduled Banks and the other Non-Scheduled Banks. Scheduled Banks are those banks included in the second schedule of the banking regulation Act, 1965 and satisfying the conditions laid down by the schedule. Non-Scheduled Banks refer to those that are not included in the second schedule of the Banking regulation Act of 1965 and do not satisfy the conditions laid down by that schedule. The primary objective of this study is to analyze the performance of Scheduled Commercial Banks since 2000 and after. The indicators selected to study are aggregate deposits, total credits, investments made by the banks and priority sector lending etc. The paper is organized as follows:

A brief overview of the commercial banking in India is provided in section-2. In section-3, review of literature is presented. Methodology is discussed in section-4. Section-5 presents the results and analysis. The conclusion of this paper is presented in section-6.

\section{Overview of Indian Commercial Banks}

The Indian financial system consists of different types of financial institutions which are responsible for the development of the country's economy. Financial institutions can broadly be classified into banking and non-banking institutions. Banking institutions are of three types: Commercial Banks, Industrial or Investment Banks and Rural Banks. The most active sector of the Indian money market is the commercial banking sector. 
Commercial banks in India can be classified into three groups; Public Sector, Private Sector and Foreign Banks. The majority of commercial banking in India is in the public sector with the State Bank of India and its associated banks. After liberalization, several private sector banks and foreign banks were allowed to open their business in the Indian financial system.

Modern banking in India was developed during the British Era. In the first half of the $19^{\text {th }}$ century, the British East India Company established three banks-the Bank of Bengal in 1809, the Bank of Bombay in 1840 and the Bank of Madras in 1843 and then these three banks were amalgamated into a new bank called Imperial Bank. Later it was taken over by the State Bank of India in 1955. For the purpose of assessment of performance of banks in India, the Reserve Bank of India which was established in 1935, categories them as a Public Sector Banks, Old Private Sector Banks, New Private Sector Banks and Foreign Banks.

\subsection{Commercial Banks and its Structure}

Commercial banks are the oldest of all types of banks. They form the base on which other types of banks developed. Commercial banks constitute the larger part of the total banking system and these banks play a vital role in the country's economy and for the general public. The commercial banking activities have a very powerful and strong influence on the Indian financial system. In India, commercial banks are established as joint stock companies with the profit motive. These banks provide short-term financial services to trade, small industry, agriculture, service sector and the general public. They accept chequable deposits called demand deposits and facilitate an easy payment mechanism. Commercial banks pool small savings and canalize the same to all the productive investments. The commercial banking structure in India consists of Scheduled Commercial Banks and Non- Scheduled Commercial Banks. Scheduled Commercial Banks constitute those banks which have been included in the second schedule of the Reserve Bank of India (RBI) Act, 1934. To become a scheduled bank, the bank has to satisfy a few conditions. Scheduled Commercial Banks enjoy several advantages from the Reserve Bank of India and can get loans in times of need.

\subsection{Banking Sector Reforms in India}

The banking sector in India has undergone remarkable changes. In 1969, 14 major banks were nationalized and in 1980, 6 major private sector banks were taken over by the government. The government did not nationalize the banks whose deposits were less than Rs.50 crore. Nationalization of commercial banks in 1968 and 1980 was a mixed blessing to the Indian banking sector. After nationalization, there was a shift of emphasis from industry to agriculture. The country witnessed rapid expansion in bank branches, even in rural areas. Banking development in India after nationalization was wonderful and received global compliments. The commercial banking system gained substantial strength to improve nation building programs. However, the nationalization process created its own problems, like excessive bureaucratization, red-tapism and disruptive tactics of trade unions by bank employees. Reforms in the commercial banking sector have two distinct phases. The first phase of reforms introduced subsequent to the release of the Report of the Committee on Financial System (Chairman-M. Narasimham), 1992 focused mainly on enabling and strengthening measures. The second phase of reforms, introduced subsequent to the recommendations of the Committee on Banking Sector Reforms (Chairman-M. Narasimham) in 1998 placed greater emphasis on structural measures and an improvement in standards of disclosure and levels of transparency, in order to align the Indian standards with the best international practices. Reforms have brought about considerable improvements, as reflected in various parameters relating to capital adequacy, asset quality, profitability and operational efficiency.

\section{Review of Literature}

A considerable amount of research has been done on the working and performance of commercial banks in India, by academicians and researchers. The literature obtained by investigators, in the form of reports of various committees, commissions and working groups established by the Union Government, Reserve Bank of India, the research studies, articles of researchers, bank officials, economists and the comments of economic analysts and news, is briefly reviewed in this part.

Hawast and John (1977) in their study concluded that profitability of banks is significantly determined by the cost control methods adopted by a particular bank. They concluded that the high profit earning banks recorded lower operating costs.

Varde and Singh (1979) in their study concluded that profitability of nationalized banks in India declined during 1964-1977 and they highlighted the cause for this decline.

Shah (1979) in his study analyzed that bank profitability is linked with bank management, customer service and financial performance etc., 
Srivastava (1981) analyzed an important reason of low profitability is because of low productivity, and low productivity could be the result of inefficient methods of operation, bad layouts, excessive product variety, not up to par working conditions, power breakdowns and poor maintenance of records.

Joshi (1986) in his study discussed the trends in profits and profitability of commercial banks since nationalization. The factors leading to the deterioration of profitability are highlighted.

Minakshi and Kaur (1990) in their study concluded that the bank rate and reserve requirements ratios have played a significant role in having a negative impact on the profitability of the banks in India.

Ojha (1992) in his study attempts to measure the productivity of commercial banks in India especially public sector. The study concludes that Indian commercial banks have less productivity compared with western countries.

Verma and Malhotra (1993) for the first time in their study have brought out frauds in commercial banks which have contributed to the declining profitability.

Mishra (1993) in his study has analyzed various factors, which have a bearing on a bank's profitability.

Raut, Kishore and Das Santosh (1996) attempted to examine and measure the profitability trend of the Indian commercial banks.

Tarapore, S.S (1999) reviewed the policy of Reserve Bank of India and its possible effect on banking sector reforms.

Das, Abraham and Ramanathan, T.V. (2000) in their study concluded that much of the lost output of Indian Commercial banks during 1998 was the result of underutilization of resources.

Shirai, Sayuri (2002) in her study analyzed the Indian banking sector reforms and consequences in detail.

Reserve Bank of India (2008) in its "Report on Trend and Progress of Banking in India-2007-08" highlighted the policy developments and the operations of commercial banks in India.

Tyrone T.Lin et al. (2009) in their research study attempted to analyze the operating performance of 117 branches of a certain bank in Taiwan in 2006.

Prof. Dr. Mohi-ud-Din Sangmi and Dr.Tabassum Nair (2010) in their research study, analyzed through the CAMEL Approach, that both the Punjab National Bank and Jammu \& Kashmir Bank have adopted prudent policies of financial management and both banks have shown significant performance as far as asset quality is concerned.

Most of the studies were made to analyze the profitability and efficiency of Indian commercial banks in both pre-reform and post-reforms eras. But none of these studies analyzed the performance of banks after the year 2000; thus, there was a need to carry out the present study.

\section{Methodology/Research Design}

The present study is diagnostic and exploratory in nature and makes use of secondary data. The relevant secondary data has been collected mainly through the data bases of Reserve Bank of India (RBI), various reports and other studies. Journals such as the Banker and the Journal of Indian Institute of Bankers have also been referred to. An attempt has been made in this paper to examine the operational performance of Scheduled Commercial Banks in India since 2000. The study is confined only to the specific areas such as Aggregate Deposits mobilized by these banks, Loans and Advances, Credit-Deposits Ratios, Investment-Deposits Ratios, for the ten years period starting from the year 2000 to the year 2009. In order to analyze the data and draw conclusions in this study, various statistical tools like Descriptive Statistics, ' $t$ 'test, and Correlation have been done using through EXCEL and SPSS Software.

\section{Results and Discussion}

\subsection{Aggregate Deposits of Scheduled Commercial Banks}

Deposits are the basic raw materials for the banks. Deposits help the banks to channel credit for productive investment in the economy. The higher the deposit mobilization is the larger the scope for deployment of funds in the economy. Deposits play a key role in commercial banking activities because the lending power of a bank and the size of its operations are determined by only the quantum of deposits. Aggregate deposits, including the demand and time deposits, are furnished in Table-1.

It is exhibited in the table 1 that the aggregate deposits mobilized by the Scheduled Commercial Banks have significantly gone up from Rs. 851,593 crores to Rs. 3,834,110 crores in the year 2000 to 2009. Demand deposits 
have been increasing year after year Rs.145, 283 crores in the year 2000 and Rs.524, 310 crores in the year 2008. The year 2009 shows decline. Compared to the demand deposits, mobilization of time deposits has been constantly rising from Rs. 707,310 crores in 2000 to Rs.3, 311,025 in 2009. The increase over the period of the study was 4.7 times.

In order to test whether the mobilization of demand deposits by the Scheduled Commercial Banks has a linear relationship with the time deposits mobilized by the banks, the CORRELATION tool was performed. The results are given in Table-2.

The mobilization of demand deposits and the time deposits of the Indian Scheduled Commercial Banks have a very strong positive correlation. The linear correlation co-efficient is 0.972096 which is very close to +1 .This means that as the demand deposits increase the time deposits are also increasing.

\subsection{Credits Deployed by Scheduled Commercial Banks}

Banks accept deposits to lend the same at a higher rate of interest. Commercial Banks are the dealers of money and suppliers of credit. They are the active participants in the process of deposit mobilization and credit creation. The year-wise credit supplied by these banks are furnished in Table-3

The data in table- 3 reveals that the Indian Scheduled Commercial Banks have been successful in performing the credit function. The credits which were Rs.454, 069 crores in 2000 have gone up to Rs.2, 775,549 crores in 2009. It is an encouraging sign that higher percentages of increase have been recorded from the year 2005 to the year 2009. The increase over the period of the study was 6.1 times.

\subsection{Investments made by Scheduled Commercial Banks}

Investment as a window of deployment of funds was given more emphasis than lending. The year-wise investments made by the banks are presented in Table- 4 .

In table-4, it's shown that Indian Scheduled Commercial Banks have been quite successful as far as investment is concerned. During the period under reference, the banks have been able to mark a rising trend in investment with Rs. 311,697 crores in the year 2000 to Rs. 739,154 crores in 2005. Although it declined in 2006, it has picked up in the subsequent years. Higher percentages of increase have been recorded in the years 2008 and 2009.

\subsection{Credit-Deposit Ratio and Investment Deposit Ratio}

Commercial banks enjoy a special privilege of credit creation by multiple expansions of deposits. Bank credit implies loans and advances. The Credit Deposit Ratio of the bank indicates the creation of credit out of the deposits .Investment-Deposit Ratio is calculated by investments made by banks, divided by the aggregate deposits of the banks. Investments of Scheduled Commercial Banks in India include only investments in government securities and other approved securities. The year-wise C-D Ratio and I-D Ratios are given in Table-5.

Table-5 reveals that the Credit Deposit Ratio of Scheduled Commercial Banks has been rising from 53.3\% in the year 2000 to $56.9 \%$ in 2003. Although the ratio declined $55.9 \%$ in 2004, it has picked up in the subsequent years. In general, the C-D Ratio shows a healthy sign as it has been increased from $53.3 \%$ in 2000 to $73.9 \%$ in the year 2009. A further analysis of the table 5 reveals that the I-D Ratios of Scheduled Commercial Banks has been constantly rising from $36.6 \%$ in 2000 to $47.3 \%$ in 2005 . From the year 2006 , this ratio shows a declining trend as more credits deployed by these banks.

A two sample ' $t$ '-test was performed to determine whether the C-D Ratio of the Scheduled Commercial Banks significantly differs from the I-D Ratio of the Scheduled Commercial Banks in India. The Hypotheses framed are as follows:

Ho: There is no difference in performance between Credit Deposit Ratio and the Investment Deposit Ratio;

H1: There is difference in performance between Credit Deposit Ratio and the Investment Deposit Ratio;

The test results are given in Table- 6 .

Table- 6 provides the result that there is strong evidence that (' $\mathrm{t}$ ' is $>2.306004$ ), HO is rejected. Hence, there is a difference in performance between the Credit Deposit Ratio and the Investment Deposit Ratio of Scheduled Commercial Banks. 


\subsection{Deposits and Credits of Scheduled Commercial Banks per Office (Rs.lakh)}

Banks accept deposits to lend the same at a higher rate of interest. Deposits and credits are just like inflow and outflow of funds of the banks. Banks deploy funds by way of providing credits to needy people. Credits (loans and advances) are the largest income earning asset of the bank and the most profitable and high risk associated item on the asset side of the bank balance sheet. Table-7 exhibits the deposits and credits of the banks per office.

The analysis of table 7 reveals that Scheduled Commercial Banks have been successful so far as deposit is concerned. During the period under reference, these banks have been able to mark a rising trend in deposits and credits, with Rs. 1,255 crores, and Rs. 669 crores respectively in the year 2000 to Rs. 4,980 crores, and Rs. 3,615 crores in 2009.

Since the co-efficient of variation of deposits of Scheduled Commercial Banks per office is less than the co-efficient of variation of credits of banks per office, deposits of Scheduled Commercial Banks per office are more consistent.

\subsection{Role of Scheduled Commercial Banks in the Priority Sector Lending}

Introducing priority sector lending is the most successful and advantageous decision of the Government of India. India is an agricultural country with a predominantly rural economy. The majority of industries are agro based. To make the agriculture sector more profitable and to increase the scope of rural industries, the government introduced the concept of priority sector. To encourage banks to participate in agricultural and rural development, the government made priority sector loans an important target for banks. Priority sector is a sector which is given priority in offering financial services of the banks. The Reserve Bank of India prescribed guidelines and targets to all the banks operating in India with regard to priority sector services. The role played by the Scheduled Commercial Banks in the priority sector lending is seen in Table-8.

It has been exhibited in table 8 that the advances made by the Scheduled Commercial Banks in priority sectors has been constantly rising from Rs.155,779 crores to Rs. 932,459 crores in the years 2000 to 2009. The increase over the period of the study was 6 times. A further analysis of table 8 demonstrates that the share of priority sector advances in total credit has been fluctuating from $31 \%$ to $36.7 \%$. The year 2005 registered a higher percentage i.e., $36.7 \%$.

\section{Conclusion}

The analysis and discussion of this research paper reveals that the operational performance of Indian Scheduled Commercial Banks has improved since the year 2000. Aggregate deposits show a constant increase. The percentage of time deposits to aggregate deposits mobilized by the Scheduled Commercial Banks was high in 2009. It was found that there is a positive correlation between demand deposits and time deposits. Credits deployed and investments made by these banks have shown significant performance. The Indian Scheduled Commercial Banks have been more efficient by maintaining the C-D ratios in an increasing trend over the period of the study. Deposits and credits of these banks per office show a constant rising year after year. The deposits of Scheduled Commercial Banks per office are greater compared to the credits per office. Improvement in investment deposit ratio and share of percentage of priority sector advances in total credit can further help in improving operational efficiency as well as the profitability of Indian Scheduled Commercial Banks. The findings may be of considerable use to banking institutions and policy makers in developing countries and to academic researchers in the area of banking performance evaluation.

\section{References}

Avkiran, N.K. (1999). The Evidence of Efficiency Gains: The Role of Mergers and the Benefits to the Public. Journal of Banking and Finance, 23, 991-1013.

Bhatia, S., and Verma, S. (1998-99). Factors Determining Profitability of Public Sector Banks in India: An Application of Multiple Regression Model. Pranjan, XXVII (4), 433-445.

Chidambaram, R.M., and Alamelu, K. (1994). Profitability in Banks, a matter of Survival. The Banker, May, 18, $1-3$.

D' Souza, Errol. (2002). How Well Have Public sector banks done? A Note. Economic and Political Weekly, March 2.

Das, Abhiman. (2002). Risk and Productivity Change of Public Sector Banks. Economic and Political Weekly, February 2. 
Dasgupta, D. (2001). Profitability of Indian Public Sector Banks in the light of Liberalization of Indian Economy: An Overview. The Management Accountant, 36(9), 693-698.

IBA (Indian Banks'Association). (1999). Performance Highlights of Banks. 1997-98, Indian Banks Association, Mumbai.

India's Best Banks. (2002). A Survey. Business India, Nov.25 to Dec. 8.

Koeve, Petya. (2003). The Performance of Indian Banks during Financial Liberalization. IMF working Paper No. 03/150.

Mathur, K.B.L. (2002). Public Sector Banks in India: Should They Be Privatized? Economic and Political Weekly, June, 8.

Mester, L.J. (1996). A Study of Bank Efficiency taking into account Risk Preferences. Journal of Banking and Finance, Vol.20, No.6, 1025-45.

Mukherjee Paramita. (2003). Dealing with NPAs: Lessons from International Experiences. Money \& Finance, January-March.

Muniappan, G.P. (2002). The NPA Overhang-Magnitude, Solutions, Legal Reforms. Address at CII Banking Summit 2002, Mumbai, April.

Narasimhan Committee. (1991). Report of the Committee on the Financial System. Government of India.

Padmanabhan, K. (1998). Financial Sector Reforms and the Performance of Commercial Banks. Political Economy Journal of India, 7 (1 and 2), 72-85.

Prof. Dr. Mohi-ud-Din Sangmi and Dr.Tabassum Nair. (2010). "Analyzing Financial Performance of Commercial Banks in India: Application of CAMEL Model” Pak. J. Commerce. Soc.Sci, Vol.4 (1), 40-55.

Professor Dilip Khankhoje and Dr. Milind Sathye. (2008). Efficiency of Rural Banks: The Case of India. International Business Research-CCSE, Vol-1, No.2.

Rangarajan, C. (1995). "Inaugural address at the 18th Bank Economists' Conference', Reserve Bank of India Bulletin, December, XLIX (12), Reserve bank of India, Mumbai.

Report on the Trend and Progress of Banking in India. (1995-96). Reserve Bank of India Bulletin, March 1007, 34-35.

Reserve Bank of India. (2008). Report on Trend and Progress of Banking in India- 2007-08. December.

Sankaranarayan, V. (1995). Performance of Public Sector Banks in 1994-95. IBA Bulletin, XVII (8), 46-48.

Sarkar, Subrata, Jayati Sarkar and Sumon K. Bhaumik. (1998). Does Ownership always Matter? Evidence from the Indian banking Industry. Journal of Comapartive Economics, Vol.26, pp.262-281.

Sathye, M. (2001). X-efficiency in Australian Banking: An Empirical Investigation. Journal of Banking and Finance, 25,613-630.

Satyadevi, C. (2009). Financial Services-Banking and Insurance. S.Chand \& Company, ISBN: 81-219-3208-4.

Second Narasimhan Committee. (1997). Committee on Banking Sector Reform, Gazette of India-Extraordinary Notification, Part II, Sec 3 (ii), Ministry of Finance, Government of India.

Shajahan, K.M. (1998). Priority Sector Bank Lending: Some Important Issues. Economic and Political Weekly, Vol.33, No.42/43 Oct, 17-30.

Sinkey, J., and F. JR. (1998). Commercial Bank Financial Management. Prentice Hall International, Inc. 69-137, $238-260$

Subramanyam, G. (1993). Productivity Growth in India's Public Sector Banks: 1979-89. Journal of Quantitative Economics, 9, 209-223.

Syed Ibrahim, M. (2010). Performance Evaluation of Regional Rural Banks in India. International Business Research-CCSE, Vol-3, No.4, October.

Thakur, S. (1990). Two Decades of Indian Banking: The Service Sector Scenario. Chanakya Publications New Delhi, India.

Tyagarajan, M. (1975). Expansion of Commercial Banking- An Assessment. Economic and Political Weekly, 10, 1819-1824. 
Tyrone T. Lin, Chia-Chi Lee \& Tsui-Fen Chiu. (2009). Application of DEA in analyzing a Bank's Operating Performance. Expert Systems with Applications: An International Journal, Vol.36-5, July.

Table 1. Aggregate Deposits of Scheduled Commercial Banks (Rs.crore)

\begin{tabular}{|l|l|l|l|l|l|}
\hline Years & $\begin{array}{l}\text { Demand } \\
\text { Deposits }\end{array}$ & $\begin{array}{l}\text { \% to Total } \\
\text { Deposits }\end{array}$ & Time Deposits & $\begin{array}{l}\text { \% to Total } \\
\text { Deposits }\end{array}$ & $\begin{array}{l}\text { Aggregate } \\
\text { Deposits }\end{array}$ \\
\hline 2000 & 145,283 & 17 & 706,310 & 83 & $\begin{array}{l}851,593 \\
(100 \%)\end{array}$ \\
\hline 2001 & 159,407 & 16 & 829,734 & 84 & $\begin{array}{l}989,141 \\
(100 \%)\end{array}$ \\
\hline 2002 & 169,103 & 15 & 962,085 & 85 & $\begin{array}{l}1,131,188 \\
(100 \%)\end{array}$ \\
\hline 2003 & 187,837 & 14 & $1,123,924$ & 86 & $\begin{array}{l}1,311,761 \\
(100 \%)\end{array}$ \\
\hline 2004 & 225,022 & 15 & $1,279,394$ & 85 & $\begin{array}{l}1,504,416 \\
(100 \%)\end{array}$ \\
\hline 2005 & 248,028 & 15 & $1,452,171$ & 85 & $\begin{array}{l}1,700,199 \\
(100 \%)\end{array}$ \\
\hline 2006 & 364,640 & 17 & $1,744,409$ & 83 & $\begin{array}{l}2,109,049 \\
(100 \%)\end{array}$ \\
\hline 2007 & 429,731 & 16 & $2,182,203$ & 84 & $\begin{array}{l}2,611,934 \\
(100 \%)\end{array}$ \\
\hline 2008 & 524,310 & 16 & $2,672,630$ & 84 & $\begin{array}{l}3,196,940 \\
(100 \%)\end{array}$ \\
\hline 2009 & 523,085 & 14 & $3,311,025$ & 86 & $\begin{array}{l}3,834,110 \\
(100 \%)\end{array}$ \\
\hline
\end{tabular}

Source: Database from Reserve Bank of India, 2009.

Table 2. Test results of Correlation

\begin{tabular}{|l|c|c|}
\hline & Demand Deposits & Time Deposits \\
\hline DD & 1 & \\
\hline TD & 0.972096 & 1 \\
\hline
\end{tabular}

Table 3. Credit of Scheduled Commercial Banks (Rs.crore)

\begin{tabular}{|l|l|l|}
\hline Years & Amount & $\begin{array}{l}\text { \% of increase over } \\
\text { previous year }\end{array}$ \\
\hline 2000 & 454,069 & -- \\
\hline 2001 & 529,271 & 17 \\
\hline 2002 & 609,053 & 15 \\
\hline 2003 & 746,432 & 23 \\
\hline 2004 & 840,785 & 13 \\
\hline 2005 & $1,100,428$ & 31 \\
\hline 2006 & $1,507,077$ & 37 \\
\hline 2007 & $1,931,190$ & 28 \\
\hline 2008 & $2,361,913$ & 22 \\
\hline 2009 & $2,775,549$ & 18 \\
\hline
\end{tabular}

Source: Database from Reserve Bank of India, 2009. 
Table 4. Investments of Scheduled Commercial Banks (Rs.crore)

\begin{tabular}{|l|l|l|}
\hline Years & Amount & $\begin{array}{c}\text { \% of increase over } \\
\text { previous year }\end{array}$ \\
\hline 2000 & 311,697 & -- \\
\hline 2001 & 367,184 & 18 \\
\hline 2002 & 437,482 & 19 \\
\hline 2003 & 547,546 & 25 \\
\hline 2004 & 677,588 & 24 \\
\hline 2005 & 739,154 & 9 \\
\hline 2006 & 717,454 & -3 \\
\hline 2007 & 791,516 & 10 \\
\hline 2008 & 971,714 & 23 \\
\hline 2009 & $1,166,410$ & 20 \\
\hline
\end{tabular}

Source: Database from Reserve Bank of India, 2009.

Table 5. C-D and I-D Ratios of Scheduled Commercial Banks

\begin{tabular}{|l|c|c|}
\hline Years & $\begin{array}{c}\text { Credit Deposit Ratio } \\
(\%)\end{array}$ & $\begin{array}{c}\text { Investment Deposit } \\
\text { Ratio (\%) }\end{array}$ \\
\hline 2000 & 53.3 & 36.6 \\
\hline 2001 & 53.5 & 37.1 \\
\hline 2002 & 53.8 & 38.7 \\
\hline 2003 & 56.9 & 41.3 \\
\hline 2004 & 55.9 & 45.0 \\
\hline 2005 & 62.6 & 47.3 \\
\hline 2006 & 70.1 & 40.0 \\
\hline 2007 & 73.5 & 35.3 \\
\hline 2008 & 74.6 & 35.5 \\
\hline 2009 & 73.9 & 35.7 \\
\hline
\end{tabular}

Source: Database from Reserve Bank of India, 2009.

Table 6. 't'-Test Results for the Credit Deposits Ration and Investment Deposits Ratio

\begin{tabular}{|l|l|l|}
\hline & CDR & IDR \\
\hline Mean & 63.86667 & 39.54444 \\
\hline Variance & 83.7425 & 18.63028 \\
\hline Observations & 9 & 9 \\
\hline Pearson Correlation & -0.4801 & \\
\hline Hypothesized Mean Difference & 0 & \\
\hline $\mathrm{df}$ & 8 & \\
\hline $\mathrm{t}$ Stat & 6.160224 & \\
\hline $\mathrm{P}(\mathrm{T}<=\mathrm{t})$ one-tail & 0.000135 & \\
\hline $\mathrm{t}$ Critical one-tail & 1.859548 & \\
\hline $\mathrm{P}(\mathrm{T}<=\mathrm{t})$ two-tail & 0.000271 & \\
\hline $\mathrm{t} C$ Critical two-tail & 2.306004 & \\
\hline
\end{tabular}


Table 7. Deposits and Credits of Scheduled Commercial Banks per Office (Rs.lakh)

\begin{tabular}{|l|l|l|}
\hline Years & $\begin{array}{l}\text { Deposits of SCBs per } \\
\text { Office }\end{array}$ & $\begin{array}{l}\text { Credits of SCBs per } \\
\text { Office }\end{array}$ \\
\hline 2000 & 1,255 & 669 \\
\hline 2001 & 1,456 & 779 \\
\hline 2002 & 1,659 & 893 \\
\hline 2003 & 1,925 & 1,143 \\
\hline 2004 & 2,265 & 1,330 \\
\hline 2005 & 2,574 & 1,700 \\
\hline 2006 & 3,047 & 2,209 \\
\hline 2007 & 3,675 & 2,757 \\
\hline 2008 & 4,344 & 3,222 \\
\hline 2009 & 4,980 & 3,615 \\
\hline Mean & 2718 & 1831.7 \\
\hline Standard Deviation & 1269.028 & 1064.382 \\
\hline Co-efficient of Variation & 47 & 58 \\
\hline
\end{tabular}

Source: Database from Reserve Bank of India, 2009.

Table 8. Advances to Priority Sectors by Scheduled Commercial Banks

\begin{tabular}{|l|l|l|}
\hline Years & Amount (Rs.crore) & $\begin{array}{l}\text { Share of Priority Sector Advances in } \\
\text { Total Credit (\%) }\end{array}$ \\
\hline 2000 & 155,779 & 35.4 \\
\hline 2001 & 182,255 & 31.0 \\
\hline 2002 & 205,606 & 34.8 \\
\hline 2003 & 254,648 & 35.1 \\
\hline 2004 & 263,834 & 34.5 \\
\hline 2005 & 381,476 & 36.7 \\
\hline 2006 & 510,175 & 35.3 \\
\hline 2007 & 632,647 & 34.3 \\
\hline 2008 & 738,686 & 32.9 \\
\hline 2009 & 932,459 & 35.2 \\
\hline
\end{tabular}

Source: Database from Reserve Bank of India, 2009. 